\title{
Building on Management Model of Modern Green University
}

\author{
Jun $\mathrm{Tu}^{1, \mathrm{a}}$, Mei-ling $\mathrm{Hu}^{2, \mathrm{~b}}$ \\ ${ }^{1}$ School of Management, Wuhan Textile University, Wuhan, China \\ ${ }^{2}$ Institute of Physical Education, South-Central University For Nationalities, Wuhan, China \\ atujun_cn@yeah.net, b842832320@qq.com
}

Keywords: Green University, Management Mode, Full Participation

\begin{abstract}
Environmental education and green university construction not only has practical significance to the construction of world class universities, but also has far-reaching educational significance to the construction of construction of ecological civilization. First of all, the domestic and foreign literature was wrote up, after reviewing the theory and summarizing the experience of construction practice. On this basis, this paper summed up the basic elements of the green university management and built a basic management framework.
\end{abstract}

\section{Introduction}

The green construction and sustainable development of university education has been paid great attention all over the world including China, the sustainable development problem of the campus gradually become a hot spot of the academia.

On the one hand, the point of view based on the university community is embedded into the regional ecological system, The United States green building council (USGBC) defines green campus as "the higher education community", which is by creating sustainable development education, healthy living and educational environment to establish improved energy efficiency, save resources, improve the environmental quality". On the other hand, based on the three basic functions of university, as higher education service of the public sector, published in the Canadian harry Fisker(Halifax) clearly pointed out that university has the role of education, research and public service can makes effective contribution in promoting the sustainable development of society.

At home and abroad has carried on the research and practice for sustainable development and green campus construction in the concept, green building standards, evaluation index system of energy conservation, environmental protection plan, sustainable campus, campus environment quality management system, green campus management and so on. However, in the current circumstances, on what is Chinese universities' sustainable development, there is short of a clear unified understanding of the main direction of building a green university, and in the management of the construction of green university, especially in soft environment lack of a more systematic research in management mode and operation mechanism. By creating such management mode, this paper designed a structured framework and management system to fill the lack of this aspect, to help university administrators and stakeholders understand the whole framework and the significance of sustainable development of higher education, so that ensure the promotion of ecological civilization concept and the concept of sustainable development in the whole society under the sustainable development of university mode.

\section{The Summarize of related research both at home and abroad}

\subsection{Comprehensive strategy management of green universities abroad}

The implementation of the green university can be divided into three stages (Leal Filho, 2009). In the first stage, university puts forward some principles of sustainable development with a lack of specific policy; In the second phase, the colleges and universities realize the importance of university of 
sustainable operation, and take sustainable development as a top target, adopt cross major, cross disciplinary, cross-sectoral integrated strategy for the holistic management. The third stage, through the adjustment of policy, seeking international certification and extensive cooperation with school stakeholders to proceed university of sustainability operation and management. It is Visible that foreign scholars tend to adopt the strategy of comprehensive management and environmental management system (EMS) to achieve the operation and management for the green university. The first to think that the management system of university campus environment includes four dimensions, namely education, research, university running and the external community (Cortese, 2003), along with the further understanding, assessment and reporting are added to the fifth dimension (Lozano, 2006).

EMS usually used types are Green building initiative (GBI and Green building initiative), ecological management and the audit plan EMAS ISO 14001 and the European Union for the university or the public sector which do not have a specific environmental management system certification. Based on this, some scholars proposed a three dimensional model, namely the implementation of the EMS, public participation and the sustainable development of the teaching and scientific research (Alshuwaikait et al, 2008). This model is substantially combined environment management system, functions of colleges and universities, and puts forward a green campus operation management pattern. But the model lack of actual concrete content only put forward a basic framework. In addition there are some scholars regard universities as a business sector and tried to introduce enterprise operation management related theories to analyze the management operation of the university. In the process of implementation, the green campus running management framework is divided into strategic layer, operation layer, community and political expectations, according to the people, processes, and place to organize, emphasized on the human factor is the most important factor in the implementation of the system, it must be animplementation of "pull oriented " rather than the policy of" push oriented " (Keoy et al., 2012).

Environmental quality management system (EMS) and public participation are very important two aspects in the operation of the green university management. It is typical that put forward by Thomas of Effective Decision Model of Public Involvement and Arne Stan theory of public participation ladder in the field of Public participation in research. In a follow-up study, the public participation in the international society will participate and empowerment of relevant public affairs and activities according to the degree of public participation are divided into five grades (IAP2, 2007) from weak to strong. Public participation's validity of empowerment and its positive influence have been proved by many scholars (Holyoak, 2001). At the same time, it is also related to the future of college students which can strengthen the students' self-skills, such as self- motivation, confidence and self -management, includes other recognized ability of openness (Harvey, 2000). In achieving sustainable development of the campus EMS dynamic mechanism, the sustainable development of the campus is from implementing standard to execute standard to execute consciously. Related study shows that no matter which kinds of EMS were chosen, bottom-up participatory and the management model and the hybrid mechanism are more effective (Antje et al, 2012).

\subsection{The domestic green university construction target and technical means}

The domestic related research focus on three aspects. One is discussing the basic target of green university construction. Green university is with people's education as the core, which integrates the principles of sustainable development and the guiding ideology into the whole process of education (Wang, 1999). Making schools have the sustainable development potential of going on and keeping pace with The Times (bird, 2003). To fully implement the ecological civilization concept and the concept of sustainable development (Wen, 2013), apply the circular economy concept to operations management of the university (Chen, 2003; Yang, 2005). Improving the ability of university in sustainable development and keeping competition (Li, 2009).

Second is technology application and index evaluation area. In the promotion work of building a conservation-minded campus that was carried out by the Department of housing construction's 
ministries. Some of these studies have made analysis about Chinese energy and resource efficiency status quo of the green campus, to explore the application of energy saving technology and the related policy issues of campus energy management (Tan et al., 2013). Using life cycle analysis try to optimize the water supply and drainage system in colleges and universities, introduce the concept of water management to colleges and universities (Han etc., 2014). At the same time, in the index evaluation, evaluation index system of the "green degree" uses the target layer, criterion layer and index layer three layer structure, aimed at education, scientific research, practice, campus construction five aspects conducting evaluation.(Chen, 2002). The composition of ecological footprint method and the ecological footprint model were applied to calculate transportation, energy, and the teachers and students 'ecological footprint and ecological efficiency in daily life in colleges and universities (Li, etc., 2005; Yao battle, etc., 2011). Taking Tami flu method as the core tools, aimed at the environmental system, environmental management and environmental education in three aspects put forward the type simple and complete green university system (Ye, 2007). And compared with the evaluation index system of major foreign sustainable campus, put forward the evaluation index system (Lv Bin etc., 2012). Domestic academic circles are short of the green campus soft management, especially the overall operation management research.

\section{The green view of university management model building}

\subsection{Management module: green education, green research services and support system}

From the overall situation at present stage, from the management point of view, the green university colleges and universities in the world roughly have the following some focus on "green university" construction practice and theoretical research results. Paying more attention to the consciousness of "green" school building thought. Building meets the requirements of the ecological livable, energy conservation and environmental protection "green university" environment. Pay attention to promote green education at the university of the overall planning and design in the student organizations and student organizations, to promote the university community environmental protection propaganda and green action, and form the behavior patterns of college students' green consumption behavior and environmental protection. Pay attention to green scientific research and throughout the concept of sustainable development and environmental protection awareness in the whole process of scientific research work of the university. Therefore, the current university of green management should take green education, green scientific research and service, and support system as the basic management module for the implementation of strategic. From the content point of view green education is integrated the related environment of knowledge and ideas into lesson plans, and connecting teacher with learning, teaching students the knowledge and skills of participating in the activities of green and low-carbon life. On the one hand, green scientific research is development and application all sorts of green energy-saving technology, which belongs to the green technology level. On the other hand it is resource consumption reduction and efficiency promotion in the process of scientific research, this belongs to low carbon economy. On system management of the soft science research can help social management decision-makers make significant policy effect simulation, to guide social practice, or to spread knowledge and skills, and transform it into productive forces promote the change of development pattern, which belongs to the green development level. Green university support system is the structures of software and hardware green university management which refers to the green university hardware facilities construction and management system construction of green university. Such as all kinds of applications of campus greening construction, energy saving and the application of pollution prevention and control technology, the energy consumption of public facilities and regulation carbon footprint of green campus, the forming of ecological information system, the green campus's traffic organization and management, the green campus's comprehensive evaluation of quality management, the green campus's cultural construction, education campaigns and green action. Which are the embodiments on specific projects of the green university construction work. 
The sustainable development strategy of green university is the specific implementation of sustainable planning framework. Bauer thought that if we want to ensure the sustainable development of the green university policy remain valid, the management must be penetrated into all aspects of the university (Bauer, 2004). But Rogers through sum up, found the consensus of scholars in the research field of sustainable development of colleges and universities is that sustainable development factors of campus education and management must be implemented into the overall design (Rogers, 2005). Therefore, according to the overall operation of colleges and universities, aimed at different characteristics and different levels of colleges and universities, try to come up with a green university construction of basic management framework. At the same time, in the process of the green university management mode and the green education management, the stakeholders, especially the participation of students, should be a important field which needs to be further studied.

Students as a social citizen or "civil society", whose realization of political rights and taking an active part in social governance and all kinds of public management decision-making and implementation is a sign of a modern civilized society. In addition, in the green university management mode and organization structure, the type and extent of relevant parties participate in the management are similar to public engagement, the relevant theory of public participation is applicable in the construction of green university.

Starting from the basic target function of colleges and universities teaching, scientific research, in our study we adopt the general classification of Chinese university, the university is divided into research based, research teaching model, teaching research oriented and teaching-style in colleges and universities. For the research based colleges and universities. Usually this type of colleges and universities have powerful scale of faculty, reasonable structure, and have the complete teaching, scientific research and experimental equipment and facilities, perfect infrastructure, school strength, this kind of green university colleges and universities management mode can refer to the advanced experience of domestic and international to build a complete green university management system, which is consist of the green university management committee (usually is the school leadership), the committee of experts (think-tank and technical consultation) and construction commission or office (coordinate various departments). For research teaching model and teaching research oriented universities, there is no strict standards to distinguish them. Such colleges and universities are attached equal importance to scientific research and teaching work, which have a graduate student education and undergraduate education, in order to cultivate creative talents with research potential, has strong research strength in several key areas and subjects, do not have the ability of comprehensive development, and it may be a bit weak in the green transformation of scientific and technological achievements and social service function. In general, there are gaps in construction funds. Such green university colleges and universities management mode should focus on the two aspects of education and scientific research. Its organization structure is suitable for the governance of weakening green management institutions and green campus management project type. In the university of teaching style the scientific research ability and related infrastructure have weaker stocks, subject setting is not complete, the influence of scientific research and social service are weak, the construction funds has greater differences according to different area and different right of jurisdiction, in the case of abundant funds, the utility will be bigger if it adopts the construction of green campus construction project type. So this kind of colleges and universities should focus on integrating the sustainable development education into the teaching, adopting the more governance of weakening green management institutions, tend to adopt the green campus management project type.

The top-down administrative instruction type and complete a participatory mixed management model from bottom to top should be used to the process of management in all kinds of universities. Top-down administrative instruction type management follow the traditional way of university management, In green management operation mode at the university of it is reflected in the setting of organization and the putting forward of organization policy and planning, the management, organization and implementation of education, scientific research, services and related 
resources and project in the strategic level .Bottom-up participatory management on the one hand, embodied in the organizational structure installation, the parties involved in the allocation of decision-making authority, On the one hand, and reflected in the participation of service performance evaluation of green university. In the management of quality evaluation, check all the work of implement in green university to correct them. Green university management operation mode as is shown in figure 1.

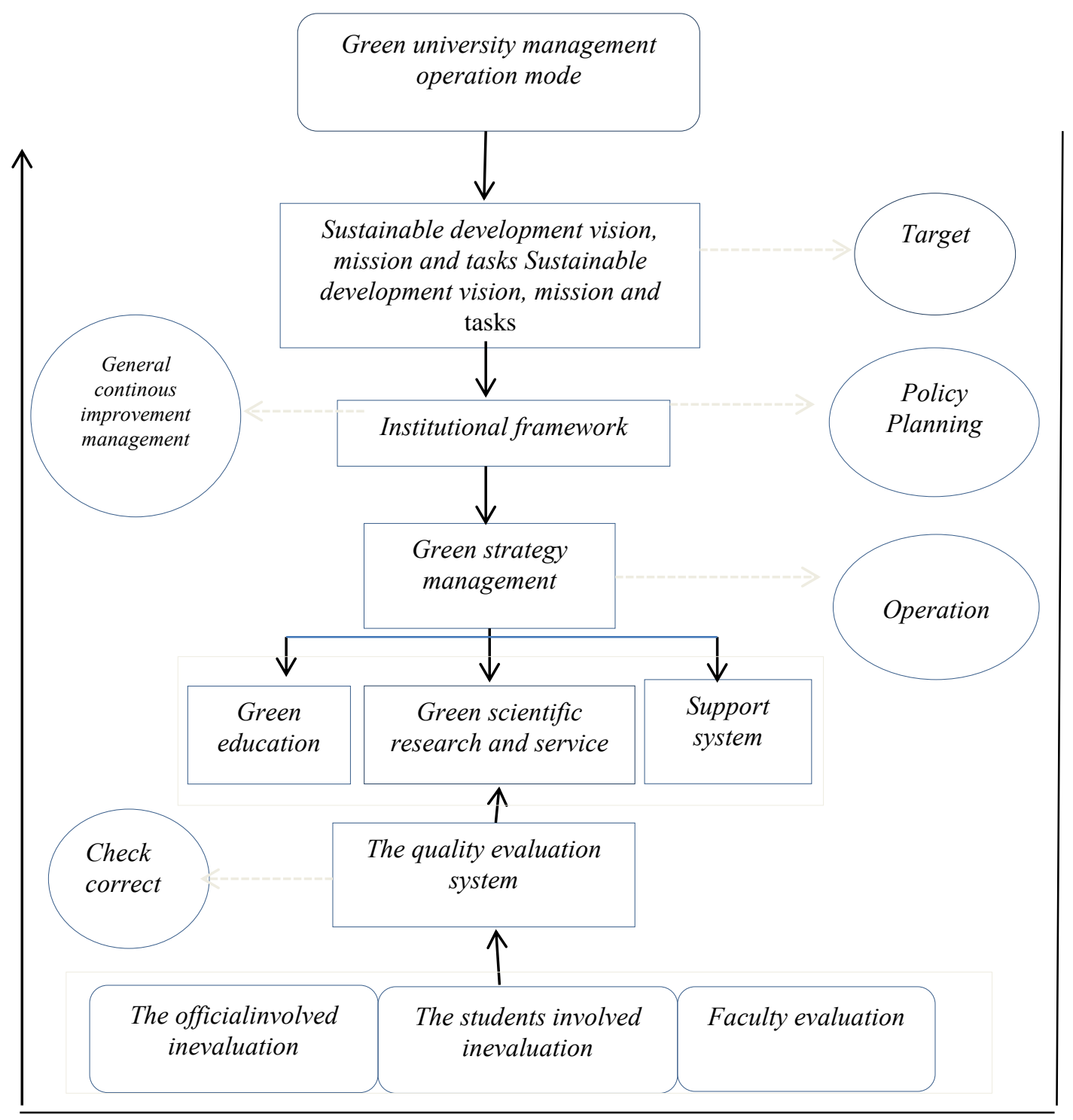

Fig. 1. This shows a figure consisting of different department of management module.

\section{Summary}

Research-oriented universities should build a complete green university management system Research teaching model and teaching research universities should focus on education and scientific research, set up a green management and coordination agency in daily management, and significant work can adopt some project managements; Teaching-oriented universities should focus on integrating the sustainable development of university education into the teaching, adopting the governance weakened green coordination management organization and the project type of green campus management. During the process of management, the green education, green scientific research and service, green campus construction and the support system is the basis of work running, total involvement in the quality evaluation system is the basis of feedback mechanism. In the 
management process, all should adopt the mixed management model that includes top-down administrative instruction type and full participatory from bottom to top.

\section{Acknowledgement}

This research was financially supported by the Soft Science Project of Science and Technology Department, Hubei Province (Grant NO.2017ADC102), Humanities and Social Sciences Project of Education Department, Hubei Province (Grant NO.16AGL024) and Education and Teaching Project of Wuhan Textile University (Grant NO.2016JY013).

\section{References}

[1] Leal F, Ed W. Sustainability at Universities Opportunities, Challenges and Trends, Peter Lang, Frankfurt, 2009:(31)134.

[2] Cortese AD. The critical role of higher education in creating a sustainable future [J]. Planning for Higher Education, 2003, 31(3):15-22.

[3] Lozano R.A tool for a graphical assessment of sustainability in universities (GASU) [J]. Journal of Cleaner Production, 2006, 14:963-972.

[4] Alshuwaikait H M, AbubakarI. An integrated approach to achieving campus sustainability: assessment of the current campus environmental management practices[J]. Journal of Cleaner Production, 2008, (16):1777-1785.

[5] Keoy K H.An Exploratory Study of Readiness and Development of Green University Framework in Malaysia [J]. ASEAN Conference on Environment-Behaviour Studies, 2012, (7):59-72.

[6] InternationalAssociation for Public Participation. Spectrum of Public Participation, 2007:58.

[7] Antje D.Environmental Management Systems (EMS) implementation processes and practices in European higher education institutions Top-down versus participatory approaches [J]. Journal of Cleaner Production, 2012, (31):81-90.

[8] Lv Bin, KanJun Jie. Western evaluation index system of sustainable campus study and its enlightenment to our country [J]. Journal of international urban planning, 2012, (27) : 44 -52.

[9] L P Fu, Jun T. University research to the enterprise technology innovation of spatial knowledge spillovers under the perspective of technology transfer [J]. Journal of management research and development, 2015, 27 (2):34 -46. 